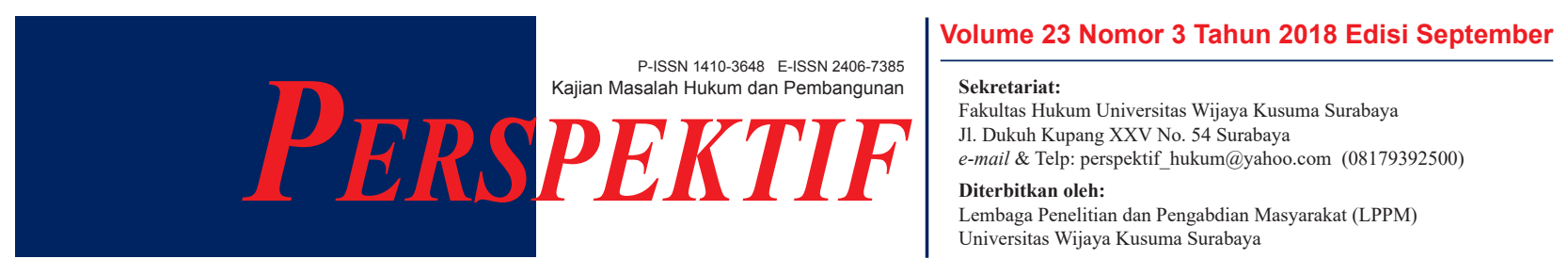

\title{
PENGGUNAAN TANAH ASET PEMERINTAH KOTA SURABAYA OLEH PIHAK KETIGA DALAM BENTUK IZIN PEMAKAIAN TANAH (PERSPEKTIF HUKUM PERTANAHAN)
}

\author{
Urip Santoso \\ Fakultas Hukum, Universitas Airlangga \\ e-mail: urip_sts@yahoo.com
}

\begin{abstract}
ABSTRAK
Pemerintah Kota Surabaya mempunyai aset berupa tanah berstatus Hak Pakai dan Hak Pengelolaan. Tanah aset Pemerintah Kota Surabaya dapat dipergunakan oleh pihak ketiga dalam bentuk Izin Pemakaian Tanah. Pemegang Izin Pemakaian Tanah berbentuk perseorangan atau badan hukum Indonesia. Pemegang Izin Pemakaian Tanah diwajibkan membayar retribusi yang besarnya ditentukan oleh Dinas Pengelolaan Bangunan dan Tanah Pemerintah Kota Surabaya. Menjadi permasalahan bahwa penggunaan tanah aset Pemerintah Kota Surabaya oleh pihak ketiga dalam bentuk Izin Pemakaian Tanah bertentangan dengan ketentuan dalam Hukum Pertanahan Nasional, hal ini disebabkan Pemerintah Kota Surabaya tidak mempunyai kewenangan untuk memperkenankan pihak ketiga yang mempergunakan tanah Hak Pakai dan Hak Pengelolaan dalam bentuk Izin Pemakaian Tanah. Hasil dari penulisan ini adalah tanah aset yang dikuasai oleh Pemerintah Kota Surabaya berstatus Hak Pakai dan Hak Pengelolaan. Hak Pakai dan Hak Pengelolaan bersifat right to use, dan tidak bersifat right of dispossal, yaitu hanya berhak mempergunakan tanah selama tanahnya dipergunakan untuk keperluan pelaksanaan tugasnya, tidak ada kewenangan untuk memindahkan hak atau menjadikan haknya sebagai jaminan utang dengan dibebani Hak Tanggungan.
\end{abstract}

Kata Kunci: Hak Pakai; Hak Pengelolaan; Izin Pemakaian Tanah

\section{ABSTRACT}

The Surabaya City Government has assets in the form of land with Right to Use and Management Rights. Land assets of the Surabaya City Government can be used by third parties in the form of Land Use Permits. Holders of Land Use Permits in the form of individuals or Indonesian legal entities. Holders of Land Use Permits are required to pay retribution, the amount of which is determined by the Surabaya City Government Building and Land Management Office It becomes a problem that the land use of Surabaya City Government assets by third parties in the form of Land Use Permits contradicts the provisions in the National Land Law, this is because the Surabaya City Government does not have the authority to allow third parties to use the Right to Use and Management Right Soil. The results of this writing are land assets that are controlled by the Surabaya City Government with the status of Use Rights and Management Rights. Use Rights and Management Rights are right to use, and are not right of disposal, that is, they only have the right to use land as long as the land is used for the purpose of carrying out their duties, there is no authority to transfer rights or make their rights guaranteed by debt. Keywords: Right to Use; Right of Land Management; Land Use Permit 


\section{PENDAHULUAN}

Dalam melaksanakan tugas pokok dan fungsinya, Pemerintah Kota Surabaya mempunyai aset (kekayaan) berbentuk benda bergerak dan benda tidak bergerak. Aset (kekayaan) berbentuk benda tidak bergerak berupa tanah dan atau bangunan. Aset (kekayaan) yang berupa tanah ada yang dipergunakan untuk kepentingannya sendiri guna keperluan rumah dinas, gedung pendidikan, gedung peribadatan, gedung olahraga, gedung pertemuan, rumah sakit/pusat kesehatan masyarakat, kantor, terminal. Aset (kekayaan) yang berupa tanah ada juga yang dipergunakan oleh pihak ketiga atas persetujuan dari Pemerintah Kota Surabaya.

Bila diidentifikasi, tanah aset yang dikuasai oleh Pemerintah Kota Surabaya berasal dari: a. Tanah yang berasal dari Gemeente Surabaia pada masa Pemerintah Hindia Belanda; b. Tanah yang berasal dari pengadaan tanah (dahulu pembebasan tanah) oleh dan untuk kepentingan Pemerintah Kota Surabaya; c. Tanah yang berasal dari ruilslag (tukar guling atau tukar bangun) antara Pemerintah Kota Surabaya dan perusahaan swasta; d. Tanah yang berasal dari bekas tanah kas desa, yaitu perubahan status administrasi dari desa menjadi kelurahan di wilayah Pemerintah Kota Surabaya; e. Tanah yang berasal dari penyerahan sarana prasarana dan utilitas umum oleh pengembang; $\mathrm{f}$. Tanah yang berasal dari penyerahan oleh perseorangan atau Badan Umum Milik Negara.

Tanah aset Pemerintah Kota Surabaya berstatus Hak Pakai dan Hak Pengelolaan. Hak Pakai dan Hak Pengelolaan yang dikuasai oleh Pemerintah Kota Surabaya berasal dari konversi hak penguasaan atas tanah negara dan pemberian hak atas tanah negara.

Di Kota Surabaya terdapat penggunaan tanah yang diakui sebagai tanah aset Pemerintah Kota Surabaya oleh perseorangan atau badan hukum Indonesia guna keperluan mendirikan bangunan ada yang berupa perjanjian penyerahan penggunaan tanah dan Izin Pemakaian Tanah. Masyarakat Kota Surabaya lebih mengenai dengan sebutan tanah surat hijau untuk tanah yang diterbitkan Izin Pemakaian Tanah.

Tanah yang diterbitkan IPT Pemerintah Kota Surabaya tersebar di beberapa wilayah Gubeng. Dharmawangsa, Gubeng Kertajaya, Gubeng Jaya, Gubeng Airlangga, Pucang, Ngagel, Bratang,
Baratajaya, Krukah, Jagir, Wonorejo, Demak Jaya, Demak Timur, Demak Selatan, Asembagus, Purwodadi, Tuban, Dukuh Kupang. IPT Pemerintah Kota Surabaya diterbitkan oleh Dinas Pengelolaan Bangunan dan Tanah.

IPT diatur dalam Peraturan Daerah Kotamadya Daerah Tingkat II Surabaya No. 1 Tahun 1997 tentang Izin Pemakaian Tanah. Peraturan Daerah Kotamadya Daerah Tingkat II Surabaya No. 1 Tahun 1997 dilaksanakan oleh Keputusan Walikotamadya Kepala Daerah Tingkat II Surabaya No. 1 Tahun 1998 tentang Tata Cara Penyelesaian Izin Pemakaian Tanah. Tanah yang diterbitkan Izin Pemakaian Tanah merupakan penggunaan tanah yang diakui sebagai aset Pemerintah Kota Surabaya oleh pihak ketiga yang berbentuk perseorangan atau badan hukum Indonesia guna keperluan mendirikan bangunan.

\section{PERUMUSAN MASALAH}

Dari uraian pendahuluan di atas, masalah yang hendak dikaji dirumuskan, yaitu apakah Izin Pemakaian Tanah sebagai bentuk penggunaan tanah aset Pemerintah Kota Surabaya oleh pihak ketiga sesuai dengan Hukum Pertanahan Nasional?

\section{PEMBAHASAN \\ Hukum Pertanahan Nasional}

Pembangunan di bidang hukum ini menjadi bertambah mendesak seiring dengan pembangunan nasional yang dilancarkan di berbagai sektor kehidupan bangsa dan terus bertambah sejalan dengan permintaan reformasi yang akhir-akhir ini sedang bergulir, sehingga dalam menyelenggarakan program pembangunan ekonomi nasional diperlukan penyesuaian di bidang hukum, oleh karena hukum yang diciptakan di dalam kondisi perekonomian tradisional atau susunan ekonomi kolonial tidak serasi lagi dengan kebutuhan-kebutuhan pengembangan ekonomi modern. ${ }^{1}$

${ }^{1}$ Fani Martiawan Kumara Putra. (2013). “Tanggung Gugat Debitur Terhadap Hilangnya Hak Atas Tanah Dalam Obyek Jaminan Hak Tanggungan". Yuridika. Fakultas Hukum Universitas Airlangga Surabaya. Volume 28 Nomor 2 Edisi Mei, h. 102-115. Lihat juga Fani Martiawan Kumara Putra. (2015). "Pembatalan Sertifikat Hak Atas Tanah Karena Cacat Administratif Serta Implikasinya Apabila Hak Atas Tanah Sedang Dijaminkan". Perspektif. Fakultas Hukum Universitas Wijaya Kusuma Surabaya. Volume 20 No. 2 Edisi Mei, h. 101117. 
Urip Santoso,

Penggunaan Tanah Aset Pemerintah Kota Surabaya Oleh Pihak Ketiga Dalam Bentuk Izin Pemakaian Tanah (Perspektif Hukum Pertanahan)

Hukum Pertanahan Nasional berlaku sejak tanggal 24 September 1960 yang ditandai dengan diundangkan Undang-Undang No. 5 Tahun 1960 tentang Peraturan Dasar Pokok-pokok Agraria, atau lebih dikenal dengan sebutan Undang-Undang Pokok Agraria (UUPA). UUPA merupakan pelaksanaan dari ketentuan Pasal 33 ayat (3) Undang-Undang Dasar Negara Republik Indonesia Tahun 1945 (UUD 1945), sebagaimana disebutkan dalam Pasal 2 ayat (1) UUPA, yaitu: "Atas dasar ketentuan dalam Pasal 33 ayat (3) Undang-Undang Dasar dan hal-hal sebagai yang dimaksud dalam Pasal 1, bumi, air, dan ruang angkasa, termasuk kekayaan alam yang terkandung di dalamnya itu pada tingkatan tertinggi dikuasai oleh Negara, sebagai organisasi kekuasaan seluruh rakyat". Pasal 33 ayat (3) UUD 1945 merupakan landasan konstitusional bagi pembentukan hukum dan politik pertanahan nasional.

UUPA secara tegas mencabut Agrarische Wet (S. 1870-55), Agrarische Besluit (S.1870-118), dan Buku II Burgerlijk Wetboek (BW) sepanjang mengenai bumi, air, dan kekayaan alam yang terkandung didalamnya, kecuali ketentuan-ketentuan mengenai hypotheek yang masih berlaku pada mulai berlakunya UUPA.

Dengan pencabutan peraturan dan keputusan yang diberlakukan oleh Pemerintah Hindia Belanda, maka terwujudlah kesatuan (unifikasi) hukum di bidang hukum pertanahan, yang menjadi salah satu tujuan diundangkan UUPA. Dengan berlakunya UUPA, maka tidak ada lagi hak atas tanah menurut hukum barat dan hak atas tanah menurut hukum adat, yang ada adalah hak atas tanah menurut hukum pertanahan, yang menjadi salah satu tujuan diundangkan UUPA, yaitu Hak Milik, Hak Guna Usaha, Hak Guna Bangunan, Hak Pakai, Hak Sewa Untuk Bangunan.

UUPA mempunyai 2 (dua) substansi dari segi berlakunya, yaitu pertama, mencabut atau menyatakan tidak berlaku peraturan dan keputusan yang dibuat oleh Pemerintah Hindia Belanda, atau tidak memberlakukan Hukum Agraria Kolonial, dan kedua, membangun Hukum Agraria Nasional berdasarkan Pancasila dan UUD 1945. Boedi Harsono menyatakan bahwa dengan berlakunya UUPA, maka terjadi perubahan secara fundamental pada Hukum Agraria di Indonesia, terutama hukum di bidang pertanahan. Perubahan yang fundamental ini mengenai struktur perangkat hukum, konsepsi yang mendasari maupun isinya. ${ }^{2}$

Dalam rangka mewujudkan kesatuan (unifikasi) hukum pertanahan, pembentuk UUPA menetapkan bahwa Hukum Adat menjadi dasar bagi pembentukan Hukum Pertanahan Nasional. Dasar pertimbangan Hukum Adat menjadi dasar bagi pembentukan Hukum Pertanahan Nasional adalah Hukum Adat dianut oleh sebagian besar rakyat Indonesia sehingga Hukum Adat tentang tanah mempunyai kedudukan yang istimewa dalam pembentukan Hukum Pertanahan Nasional. Hukum Adat menjadi dasar bagi pembentukan Hukum Pertanahan Nasional ditetapkan dalam Pasal 5 UUPA, yaitu: "Hukum Agraria yang berlaku atas bumi, air, dan ruang angkasa ialah hukum adat, sepanjang tidak bertentangan dengan kepentingan nasional dan negara, yang berdasarkan atas persatuan bangsa, dengan sosialisme Indonesia serta dengan peraturanperaturan yang tercantum dalam Undang-Undang ini dan dengan peraturan perundangan lainnya, segala sesuatu dengan mengindahkan unsur-unsur yang bersandar pada hukum agama".

Tujuan diundangkan UUPA disebutkan dalam Penjelasan Umumnya, yaitu: a. meletakkan dasardasar bagi penyusunan Hukum Agraria Nasional yang akan merupakan alat untuk membawakan kemakmuran, kebahagiaan, dan keadilan bagi negara dan rakyat terutama rakyat tani dalam rangka masyarakat yang adil dan makmur; $b$. meletakkan dasar-dasar untuk mengadakan kesatuan dan kesederhanaan dalam Hukum Pertanahan; c. meletakkan dasar-dasar untuk memberikan kepastian hukum mengenai hak-hak atas tanah bagi rakyat seluruhnya.

UUPA tidak hanya mengatur tentang tanah, tetapi mengatur tentang agraria, yang meliputi bumi, air, ruang angkasa, dan kekayaan alam yang terkandung di dalamnya. UUPA mengatur sebagian besar tentang tanah.

\section{Status Tanah Aset Pemerintah Kota Surabaya}

Hak atas permukaan bumi atau hak atas tanah yang ditetapkan dalam Pasal 4 ayat (1) UUPA, yaitu atas dasar hak menguasai negara ditentukan

2 Boedi Harsono. (2003). Hukum Agraria Indonesia Sejarah Pembentukan Undang-Undang Pokok Agraria Isi dan Pelaksanaannya. Jakarta: Djambatan, h. 1. 
adanya macam-macam hak atas permukaan bumi, yang disebut tanah, yang dapat diberikan kepada dan dipunyai oleh orang-orang, baik sendiri maupun bersama-sama dengan orang lain dan badan-badan hukum.

Hak atas permukaan bumi atau hak atas tanah yang disebutkan dalam Pasal 4 ayat (1) UUPA, dijabarkan macamnya dalam Pasal 16 ayat (1) UUPA dan Pasal 53 ayat (1) UUPA. Pasal 16 ayat (1) UUPA menetapkan macam hak atas tanah, yaitu Hak Milik, Hak Guna Usaha, Hak Guna Bangunan, Hak Pakai, Hak Sewa Untuk Bangunan, Hak Membuka Tanah, Hak Memungut Hasil Hutan, dan hak atas tanah yang akan ditetapkan dengan Undang-Undang. Pasal 53 ayat (1) UUPA menetapkan macam hak atas tanah yang bersifat sementara, yaitu Hak Gadai, Hak Usaha Bagi Hasil, Hak Menumpang, dan Hak Sewa Tanah Pertanian.

Boedi Harsono menyatakan bahwa tanah dalam pengertian yuridis menurut UUPA adalah permukaan bumi, sedangkan hak atas tanah adalah hak atas permukaan bumi yang berbatas, berdimensi dua dengan ukuran panjang dan lebar. ${ }^{3}$ Yang dimaksud dengan hak atas tanah adalah hak yang memberikan wewenang kepada pemegang haknya untuk mempergunakan dan/atau mengambil manfaat dari tanah yang dikuasai.

Dari macam-macam hak atas tanah yang disebutkan di atas, status tanah yang dapat dikuasai oleh Pemerintah Kota Surabaya, yaitu:

\section{a. Hak Pakai}

Pengertian Hak Pakai menurut Pasal 41 ayat (1) UUPA adalah: "Hak untuk menggunakan dan atau memungut hasil dari tanah yang dikuasai langsung oleh negara atau tanah milik orang lain, yang memberi wewenang dan kewajiban yang ditentukan dalam keputusan pemberiannya oleh pejabat yang berwenang memberikannya atau dengan perjanjian dengan pemilik tanahnya, yang bukan perjanjian sewa menyewa atau perjanjian pengolahan tanah, segala sesuatu asal tidak bertentangan dengan jiwa dan ketentuan-ketentuan Undang-Undang ini".

Peraturan perundang-undangan yang menetapkan bahwa Pemerintah Kota Surabaya sebagai Pemerintah Daerah dapat menguasai tanah Hak Pakai, adalah: a. Pasal 42 UUPA; b. Pasal 1 Peraturan Menteri Agraria No. 9 Tahun 1965 tentang

3 ibid., h. 86.
Pelaksanaan Konversi Hak Penguasaan Atas Tanah Negara dan Kebijaksanaan Selanjutnya; c. Pasal 1 huruf a Peraturan Menteri Agraria No. 1 Tahun 1966 tentang Pendaftaran Hak Pakai dan Hak Pengelolaan; d. Pasal 39 Peraturan Pemerintah No. 40 Tahun 1996 tentang Hak Guna Usaha, Hak Guna Bangunan, dan Hak Pakai Atas Tanah; e. Pasal 49 Peraturan Menteri Negara Agraria/Kepala Badan Pertanahan Nasional No. 9 Tahun 1999 tentang Tata Cara Pemberian dan Pembatalan Pemberian Hak Atas Tanah Negara dan Hak Pengelolaan.

Tanah Hak Pakai yang dikuasai oleh Pemerintah Kota Surabaya diperoleh melalui konversi hak penguasaan atas tanah negara dan permohonan pemberian hak atas tanah negara.

Hak Pakai ada yang bersifat privat, yaitu Hak Pakai yang dikuasai oleh warga negara Indonesia, orang asing yang berkedudukan di Indonesia, Perseroan Terbatas, atau perusahaan asing yang mempunyai perwakilan di Indonesia. Hak Pakai ada juga yang bersifat publik, yaitu Hak Pakai yang dikuasai oleh Lembaga Negara, Kementerian, Lembaga Pemerintah Non Kementerian, Pemerintah Provinsi, Pemerintah Kabupaten/Kota, Badan Otorita, Perwakilan Negara Asing, Perwakilan Badan Internasional, badan keagamaan, dan badan sosial. A.P. Parlindungan menyatakan bahwa Hak Pakai yang dipunyai oleh badan hukum publik disebut Hak Pakai Publik ada right to use, yaitu menggunakannya untuk waktu yang tidak terbatas selama pelaksanaan tugas, namun tidak ada right of dispossal, yaitu tidak dapat dialihkan dalam bentuk apapun kepada pihak ketiga dan juga tidak dapat dijadikan objek Hak Tanggungan. ${ }^{4}$ Pihak yang menguasai tanah Hak Pakai yang bersifat publik mempunyai kewenangan untuk mempergunakan tanah Hak Pakai untuk waktu yang tidak terbatas dan berlaku selama tanah Hak Pakai dipergunakan untuk kepentingan pelaksanaan tugas, tetapi tidak mempunyai kewenangan untuk memindahkan tanah Hak Pakai kepada pihak lain dan menjadikan jaminan utang dengan dibebani Hak Tanggungan.

Ketentuan-ketentuan tentang Hak Pakai yang dikuasai oleh Pemerintah Kota Surabaya dapat dilihat dari beberapa aspek, yaitu pertama, aspek

\footnotetext{
${ }^{4}$ A.P. Parlindungan. (Maret-April 1991). "Beberapa Konsep tentang Hak-Hak Atas Tanah". Majalah CSIS. Jakarta. Tahun XX No. 2, h. 135
} 
Urip Santoso,

Penggunaan Tanah Aset Pemerintah Kota Surabaya Oleh Pihak Ketiga Dalam Bentuk Izin Pemakaian Tanah (Perspektif Hukum Pertanahan)

penggunaan tanahnya, Hak Pakai dipergunakan untuk kepentingan pelaksanaan tugas Pemerintah Kota Surabaya; kedua, aspek masa penguasaan tanahnya, Hak Pakai tidak berjangka waktu tertentu, melainkan berlaku selama tanahnya dipergunakan untuk kepentingan pelaksanaan tugasnya; ketiga, aspek sifatnya, Hak Pakai bersifat right to use tidak bersifat right of dispossal; keempat, aspek peralihan haknya, Hak Pakai ini tidak dapat dialihan dalam bentuk apapun kepada pihak lain; kelima, aspek pembebanan haknya, Hak Pakai ini tidak dapat dijadikan jaminan utang dengan dibebani Hak Tanggungan; keenam, pihak ketiga yang memperoleh Hak Pakai ini melalui pelepasan Hak Pakai oleh walikota setelah mendapatkan persetujuan dari Dewan Perwakilan Rakyat Daerah (DPRD) Kota Surabaya; dan ketujuh, Hak Pakai yang berupa tanah kosong tanah bangunan di atasnya tidak dapat disewakan oleh Pemerintah Kota Surabaya kepada pihak ketiga sebab tanah yang dapat disewakan adalah tanah berstatus Hak Milik.

\section{b. Hak Pengelolaan}

Pasal 1 angka 2 Peraturan Pemerintah No. 40 Tahun 1996 juncto Pasal 1 angka 4 Peraturan Pemerintah No. 24 Tahun 1997 tentang Pendaftaran Tanah memberikan pengertian tentang Hak Pengelolaan, yaitu hak menguasai negara yang kewenangan pelaksanaannya sebagian dilimpahkan kepada pemegang haknya. Pasal 2 ayat (3) UndangUndang No 20 Tahun 2000 tentang Perubahan Atas Undang-Undang Nomor 21 Tahun 1997 tentang Bea Perolehan Hak Atas Tanah dan Bangunan juncto Pasal 1 Peraturan Pemerintah No. 112 Tahun 2000 tentang Pengenaan Bea Perolehan Hak Atas Tanah dan Bangunan Karena Pemberian Hak Pengelolaan memberikan pengertian yang lebih lengkap tentang Pemerintah Kabupaten/Kota sebagai pemegang Hak Pengelolaan disebutkan dalam: a. Pasal 5 Peraturan Menteri Agraria No. 9 Tahun 1965; b. Pasal 1 huruf b Peraturan Menteri Agraria No. 1 Tahun 1966; c. Pasal 5 dan Pasal 6 Peraturan Menteri Dalam Negeri No. 5 Tahun 1974 tentang Ketentuan-ketentuan Mengenai Penyediaan dan Pemberian Tanah Untuk Keperluan Perusahaan; d. Pasal 2 Peraturan Pemerintah No. 36 Tahun 1997 tentang Pengenaan Bea Perolehan Hak Atas Tanah dan Bangunan Karena Pemberian Hak Pengelolaan; e. Pasal 67 Peraturan Menteri Negara
Agraria/Kepala Badan Pertanahan Nasional No. 9 Tahun 1999.

Hak Pengelolaan diberikan kepada badan-badan hukum tertentu, yaitu instansi Pemerintah termasuk Pemerintah Daerah, Badan Usaha Milik Negara, Badan Usaha Milik Daerah, PT Persero, Badan Otorita, dan badan-badan hukum Pemerintah lainnya yang ditunjuk oleh Pemerintah. Tidak setiap badan hukum dapat mempunyai Hak Pengelolaan. Badan hukum yang dapat mempunyai Hak Pengelolaan adalah badan hukum hukum yang tugas pokok dan fungsinya berkaitan dengan pengelolaan tanah.

Salah satu subjek Hak Pengelolaan adalah Pemerintah Kota Surabaya sebagai Pemerintah Daerah. Pemerintah Kota Surabaya memenuhi syarat sebagai subjek Hak Pengelolaan sebab Pemerintah Kabupaten/Kota mempunyai tugas pokok dan fungsi berkaitan dengan pengelolaan tanah.

Setiap hak penguasaan atas tanah dimuati hak, kewajiban, dan wewenang bagi pemegang haknya. Demikian pula dengan Hak Pengelolaan di dalamnya terdapat wewenang bagi pemegang haknya. Dalam Undang-Undang No. 20 Tahun 2000 juncto Peraturan Pemerintah No. 112 Tahun 2000 dimuat wewenang dalam pengertian Hak Pengelolaan, yaitu pertama, merencanakan peruntukan dan penggunaan tanah; kedua, mempergunakan tanah untuk keperluan pelaksanaan tugasnya; dan ketiga, menyerahkan bagian-bagian tanah Hak Pengelolaan kepada pihak ketiga dan atau bekerja sama dengan pihak ketiga.

Tanah Hak Pengelolaan yang dikuasai oleh Pemerintah Kota Surabaya diperoleh melalui konversi hak penguasaan atas tanah Negara dan permohonan pemberian hak atas tanah Negara.

Ketentuan-ketentuan tentang Hak Pengelolaan yang dikuasai oleh Pemerintah Kota Surabaya dapat dilihat dari beberapa aspek, yaitu pertama, aspek kewenangan, Pemerintah Kota Surabaya sebagai pemegang Hak Pengelolaan berwenang merencanakan peruntukan dan penggunaan tanah, mempergunakan tanah untuk keperluan pelaksanaan tugasnya; dan menyerahkan bagian-bagian tanah Hak Pengelolaan kepada pihak ketiga dan atau bekerja sama dengan pihak ketiga; kedua, aspek penggunaan tanahnya, Hak Pengelolaan dipergunakan untuk kepentingan pelaksanaan tugas Pemerintah Kota Surabaya, atau dipergunakan oleh pihak ketiga atas persetujuan Pemerintah Kota Surabaya; ketiga, 
aspek masa penguasaan tanahnya, Hak Pengelolaan tidak berjangka waktu tertentu, melainkan berlaku selama tanahnya dipergunakan untuk kepentingan pelaksanaan tugasnya; keempat, aspek sifatnya, Hak Pengelolaan bersifat right to use tidak bersifat right of dispossal; kelima, aspek peralihan haknya, Hak Pengelolaan ini tidak dapat dialihan dalam bentuk apapun kepada pihak lain; keenam, aspek pembebanan haknya, Hak Pengelolaan ini tidak dapat dijadikan jaminan utang dengan dibebani Hak Tanggungan; ketujuh, pihak ketiga yang ingin memperoleh tanah Hak Pengelolaan untuk selama-lamanya ditempuh melalui pelepasan Hak Pengelolaan oleh walikota setelah mendapatkan persetujuan dari Dewan Perwakilan Rakyat Daerah (DPRD) Kota Surabaya; dan kedelapan, Hak Pengelolaan yang berupa tanah kosong tanah bangunan di atasnya tidak dapat disewakan oleh Pemerintah Kota Surabaya kepada pihak ketiga sebab tanah yang dapat disewakan adalah tanah berstatus Hak Milik.

\section{Pengaturan Izin Pemakaian Tanah}

Dalam rangka hubungan hukum antara Pemerintah, termasuk Pemerintah Daerah dan masyarakat, maka dibentuklah izin. Izin merupakan instrumen yang dimiliki oleh Pemerintah, termasuk Pemerintah Daerah untuk mengendalikan kegiatan yang dilakukan oleh masyarakat sesuai dengan caracara yang ditetapkan dalam peraturan perundangundangan. Suatu izin yang diberikan oleh Pemerintah, termasuk Pemerintah Daerah memiliki maksud untuk menciptakan kondisi yang aman dan tertib agar setiap kegiatan sesuai dengan peruntukannya.

Menurut Philipus M. Hadjon, izin adalah persetujuan dari Pemerintah berdasarkan UndangUndang atau Peraturan Pemerintah untuk dalam keadaan tertentu menyimpang dari ketentuan larangan perundangan. ${ }^{5}$ Arief Sidharta menyatakan bahwa izin adalah pembolehan khusus untuk melakukan sesuatu yang secara umum dilarang. ${ }^{6}$ Izin adalah persetujuan yang ditetapkan oleh Pemerintah, termasuk Pemerintah Daerah yang diterbitkan berdasarkan peraturan perundang-undangan,

5 Philipus M. Hadjon. (1993). "Pengantar Hukum Perizinan". YURIDIKA. Surabaya: Fakultas Hukum Universitas Airlangga, h. 2.

6 Arief Shidarta. (1996). Refleksi Tentang Hukum Pengertian-Pengertian Dasar Dalam Teori Hukum. Bandung: Citra Aditya Bakti, h. 101. diberikan kepada perseorangan atau badan hukum, untuk dalam keadaan tertentu menyimpang dari ketentuan larangan yang ditetapkan dalam peraturan perundang-undangan. Izin berarti menghilangkan suatu larangan yang semula dilarang menjadi diperbolehkan oleh Pemerintah, termasuk Pemerintah Daerah. Pada dasarnya, izin memuat persetujuan sebagai pengecualian untuk melakukan sesuatu kegiatan yang sebenarnya dilarang. Pengecualian tersebut harus diberikan oleh peraturan perundangundangan untuk menunjukkan legalitas sebagai ciri negara hukum yang demokratis. Dengan memberikan izin, Pemerintah, termasuk Pemerintah Daerah memperkenankan seseorang atau badan hukum yang mengajukan permohonan untuk melakukan suatu kegiatan tertentu yang sebenarnya dilarang.

Tatiek Sri Djatmiati menyatakan bahwa izin adalah suatu sarana hukum yang dipakai oleh Pemerintah dalam mengendalikan kehidupan masyarakat agar tidak menyimpang dari ketentuan hukum yang berlaku. Izin juga merupakan instrumen yuridis yang dipergunakan oleh Pemerintah dalam pelayanan masyarakat. ${ }^{7}$ Izin merupakan sarana hukum yang dipergunakan oleh Pemerintah, termasuk Pemerintah Daerah untuk mengendalikan kegiatan masyarakat dan memberikan pelayanan kepada masyarakat.

Maksud dan tujuan izin adalah selain sebagai sarana untuk mengendalikan masyarakat dalam beraktifitas agar tidak mengganggu tetangga dan lingkungannya, juga merupakan legitimasi atas kegiatan yang dilakukan oleh pemegang izin sehingga pemegang izin merasa aman bahwa kegiatan tersebut tidak melanggar hukum serta tidak akan diprotes oleh orang lain. ${ }^{8}$ Tujuan izin di samping untuk mengendalikan kegiatan masyarakat dan menjadi legitimasi bagi pemegang izin untuk mengadakan suatu kegiatan yang sebenarnya dilarang.

Pemakaian tanah aset Pemerintah Kota Surabaya oleh pihak ketiga semula diatur dalam Peraturan

${ }^{7}$ Tatiek Sri Djatmiati. "Kerjasama Antar Daerah Dalam Bidang Perizinan", Majalah YURIDIKA. Vol. XX No. 4 JuliAgustus 2005. Surabaya: Fakultas Hukum Universitas Airlangga, h. 258 .

${ }^{8}$ Lilik Pudjiastuti. "Kewenangan Pelayanan Perizinan di Pemerintah Kota Surabaya dengan Diberlakukannya UndangUndang No. 22 Tahun 1999". Majalah YURIDIKA. Vol. XVII No. 6 November-Desember 2003. Surabaya: Fakultas Hukum Universitas Airlangga, h. 556. 
Urip Santoso,

Penggunaan Tanah Aset Pemerintah Kota Surabaya Oleh Pihak Ketiga Dalam Bentuk Izin Pemakaian Tanah (Perspektif Hukum Pertanahan)

Daerah Kotamadya Daerah Tingkat II Surabaya No. 3 Tahun 1987 tentang Pemakaian Tanah atau Tempattempat Yang Dikuasai Oleh Pemerintah Kotamadya Daerah Tingkat II Surabaya. Peraturan Daerah dinyatakan tidak berlaku lagi oleh Peraturan Daerah Kotamadya Daerah Tingkat II Surabaya No. 12 Tahun 1994 tentang Pemakaian Tanah atau Tempat-tempat Yang Dikuasai Oleh Pemerintah Kotamadya Daerah Tingkat II Surabaya. Peraturan Daerah Kotamadya Daerah Tingkat II Surabaya No. 12 Tahun 1994 dinyatakan tidak berlaku lagi oleh Peraturan Daerah Kotamadya Daerah Tingkat II Surabaya No. 1 Tahun 1997 tentang Izin Pemakaian Tanah.

Peraturan yang melaksanakan pemakaian tanah aset Pemerintah Kota Surabaya oleh pihak ketiga semula diatur dalam Keputusan Walikotamadya Kepala Daerah Tingkat II Surabaya No. 202 Tahun 1987. Keputusan Walikotamadya Kepala Daerah Tingkat II Surabaya No. 202 Tahun 1987dinyatakan tidak berlaku lagi oleh Keputusan Walikotamadya Kepala Daerah Tingkat II Surabaya No. 22 Tahun 1993 tentang Tata Cara Penyelesaian Izin Pemakaian Tanah atau Tempat-tempat Yang Dikuasai Oleh Pemerintah Kotamadya Daerah Tingkat II Surabaya. Keputusan Walikotamadya Kepala Daerah Tingkat II Surabaya No. 22 Tahun 1993 dinyatakan tidak berlaku lagi oleh Keputusan Walikotamadya Kepala Daerah Tingkat II Surabaya No. 1 Tahun 1998 tentang Tata Cara Penyelesaian Izin Pemakaian.

Pengertian Izin Pemakaian Tanah disebutkan dalam Pasal 1 huruf f Peraturan Daerah Kotamadya Daerah Tingkat II Surabaya No. 1 Tahun 1997 juncto Pasal 1 huruf e Keputusan Walikotamadya Kepala Daerah Tingkat II Surabaya No. 1 Tahun 1998, yaitu: "Izin Pemakaian Tanah adalah izin yang diberikan oleh Walikotamadya Kepala Daerah atau pejabat yang ditunjuk untuk memakai tanah dan bukan merupakan pemberian Hak Pakai atau hak-hak atas tanah lainnya sebagaimana diatur dalam UndangUndang No. 5 Tahun 1960".

Berdasarkan pengertian Izin Pemakaian Tanah di atas menunjukkan bahwa Izin Pemakaian Tanah diberikan oleh Walikotamadya Kepala Daerah (Walikota Surabaya) atau pejabat yang ditunjuk yaitu Kepala Dinas Pengelolaan Bangunan dan Tanah, maksud diterbitkan Izin Pemakaian Tanah adalah untuk memakai tanah, dan hak yang diberikan kepada pemegang Izin Pemakaian Tanah adalah bukan Hak
Pakai atau hak-hak atas tanah lainnya sebagaimana diatur dalam Undang-Undang No. 5 Tahun 1960.

Tanah yang diterbitkan Izin Pemakaian Tanah menurut Pasal 1 hurufe Peraturan Daerah Kotamadya Daerah Tingkat II Surabaya No. 1 Tahun 1997 juncto Pasal 1 huruf h Keputusan Walikotamadya Kepala Daerah Tingkat II Surabaya No. 1 Tahun 1998, yaitu tanah milik dan atau dikuasai/dikelola oleh Pemerintah Kota Surabaya.

Penerbitan Izin Pemakaian Tanah dibagi menjadi 3 (tiga) katagori, yaitu: a. Katagori peresmian, yaitu penerbitan Izin Pemakaian Tanah yang sebelumnya pernah diterbitkan izin; b. Katagori perpanjangan, yaitu penerbitan Izin Pemakaian Tanah yang baru guna menggantikan Izin Pemakaian Tanah yang masa berlakunya sudah berakhir; c. Katagori pengalihan, yaitu penerbitan Izin Pemakaian Tanah yang baru sebagai akibat terjadinya pengalihan hak karena jual beli, hibah, atau warisan.

Penerbitan Izin Pemakaian Tanah dibagi menjadi 3 (tiga) klasifikasi, yaitu: a. Klasifikasi I, yaitu Izin Pemakaian Tanah jangka panjang, yang berlaku selama 20 (duapuluh) tahun dan dapat diperpanjang setiap kali paling lama selama 20 (duapuluh) tahun khusus untuk usaha dan perumahan; b. Klasifikasi II, yaitu Izin Pemakaian Tanah jangka menengah, yang berlaku selama 5 (lima) tahun dan dapat diperpanjang setiap kali paling lama selama 5 (lima) tahun; c. Klasifikasi III, yaitu Izin Pemakaian Tanah jangka pendek, yang berlaku selama 2 (dua) tahun dan dapat diperpanjang setiap kali paling lama selama 2 (dua) tahun.

Izin Pemakaian Tanah ditandatangani oleh Sekretaris Kota Surabaya. Kutipan Izin Pemakaian Tanah ditandatangani oleh Kepala Dinas Pengelolaan Bangunan dan Tanah Pemerintah Kota Surabaya. Izin Pemakaian Tanah diterbitkan Dinas Pengelolaan Bangunan dan Tanah Pemerintah Kota Surabaya.

Pemegang Izin Pemakaian Tanah mempunyai kewajiban, yaitu: a. Membayar retribusi sesuai ketentuan yang berlaku; b. Mematuhi dan mentaati semua ketentuan yang ditetapkan dalam Surat Izin Pemakaian Tanah; c. Memakai tanah sesuai dengan peruntukan tanah sebagaimana tersebut dalam Surat Izin Pemakaian Tanah; d. Pemegang Izin Pemakaian Tanah dilarang mengalihkan Izin Pemakaian Tanah kepada pihak lain tanpa persetujuan tertulis terlebih dahulu dari Walikota Surabaya, pejabat yang 
ditunjuk, yaitu Kepala Dinas Pengelolaan Bangunan dan Tanah Pemerintah Kota Surabaya; e. Dalam hal pemegang Izin Pemakaian Tanah meninggal dunia, yang berkepentingan (ahli waris) dapat melanjutkan Izin Pemakaian Tanah dimaksud dengan mengajukan permohonan terlebih dahulu kepada Walikota Surabaya, pejabat yang ditunjuk, yaitu Kepala Dinas Pengelolaan Bangunan dan Tanah Pemerintah Kota Surabaya untuk mendapatkan Surat Izin Pemakaian Tanah baru sesuai ketentuan yang berlaku; f. Apabila bangunan di atas tanah yang diterbitkan Izin Pemakaian Tanah akan dijadikan agunan atau jaminan atas suatu pinjaman, pemegang Izin Pemakaian Tanah terlebih dahulu harus memperoleh persetujuan tertulis dari Walikota Surabaya, pejabat yang ditunjuk, yaitu Kepala Dinas Pengelolaan Bangunan dan Tanah Pemerintah Kota Surabaya; g. Apabila Surat Izin Pemakaian Tanah yang masih berlaku hilang, pemegang Izin Pemakaian Tanah harus segera mengajukan permohonan turunan Surat Izin Pemakaian Tanah kepada Walikota Surabaya, pejabat yang ditunjuk, yaitu Kepala Dinas Pengelolaan Bangunan dan Tanah Pemerintah Kota Surabaya.

Hak-hak yang dimiliki oleh pemegang Izin Pemakaian Tanah, yaitu: a. Memakai tanah sesuai peruntukan tanahnya yang tercantum dalam Surat Izin Pemakaian Tanah; b. Mendirikan bangunan untuk usaha atau perumahan di atas tanah yang diterbitkan Surat Izin Pemakaian Tanah; c. Mengalihkan Surat Izin Pemakaian Tanah kepada pihak lain melalui jual beli, hibah, atau warisan; d. Mengagunkan atau menjaminkan bangunan di atas tanah Surat Izin Pemakaian Tanah untuk suatu utang piutang.

Surat Izin Pemakaian Tanah dapat dicabut oleh Walikota Surabaya, apabila: a. Tanah yang di atasnya terdapat Surat Izin Pemakaian Tanah dibutuhkan untuk kepentingan umum; b. Pemegang Surat Izin Pemakaian Tanah melanggar atau tidak memenuhi ketentuan yang ditetapkan dalam Surat Izin Pemakaian Tanah; c. Tanah dibiarkan kosong dan atau ditelantarkan hingga 3 (tiga) tahun sejak diterbitkan Surat Izin Pemakaian Tanah; d. Ternyata di kemudian hari diketahui bahwa persyaratan yang diajukan untuk mendapatkan Surat Izin Pemakaian Tanah tidak dapat dipertanggungjawabkan atau tidak benar.
Surat Izin Pemakaian Tanah dapat berakhir apabila: a. Masa berlakunya Surat Izin Pemakaian Tanah berahir dan pemegang Surat Izin Pemakaian Tanah tidak memperpanjang Surat Izin Pemakaian Tanah sesuai dengan ketentuan yang berlaku; b. Atas permintaan pemegang Surat Izin Pemakaian Tanah; c. Pemegang Surat Izin Pemakaian Tanah meninggal dunia; d. Surat Izin Pemakaian Tanah dicabut oleh Walikota Surabaya.

\section{Kesesuaian Izin Pemakaian Tanah Dari Kajian Hukum Pertanahan Nasional}

Izin Pemakaian Tanah merupakan bentuk penggunaan tanah aset Pemerintah Kota Surabaya oleh pihak ketiga. Selain Izin Pemakaian Tanah terdapat bentuk lain penggunaan tanah aset Pemerintah Kota Surabaya oleh pihak ketiga, yaitu Perjanjian Penggunaan Tanah, atau Perjanjian Bangun Guna Serah atau Perjanjian Build Operate and Transfer (BOT). Tanah yang diterbitkan Izin Pemakaian Tanah adalah tanah yang berstatus Hak Pakai atau Hak Pengelolaan Pemerintah Kota Surabaya.

Izin Pemakaian Tanah dapat diberikan kepada perseorangan atau badan hukum yang didirikan menurut hukum Indonesia dan berkedudukan di Indonesia. Perseorangan atau badan hukum yang didirikan menurut hukum Indonesia dan berkedudukan di Indonesia guna keperluan mendirikan bangunan berupa perumahan atau usaha. Perseorangan atau badan hukum yang memakai tanah Hak Pakai atau Hak Pengelolaan Pemerintah Kota Surabaya harus memiliki Izin Pemakaian Tanah.

Izin Pemakaian Tanah diterbitkan oleh Dinas Pengelolaan Bangunan dan Tanah Pemerintah Kota Surabaya. Perseorangan atau badan hukum yang ingin mendaptkan Izin Pemakaian Tanah harus mengajukan permohonan secara tertulis kepada Kepala Dinas Pengelolaan Bangunan dan Tanah Pemerintah Kota Surabaya.

Menurut Pasal 1 huruf f Peraturan Daerah Kotamadya Daerah Tingkat II Surabaya No. 1 Tahun 1997 juncto Pasal 1 huruf i Keputusan Walikotamadya Kepala Daerah Tingkat II Surabaya No. 1 Tahun 1998, Izin Pemakaian Tanah adalah izin yang diberikan oleh Walikotamadya Kepala Daerah atau pejabat yang ditunjuk untuk memakai tanah dan bukan merupakan pemberian Hak Pakai atau hak-hak 
Urip Santoso,

Penggunaan Tanah Aset Pemerintah Kota Surabaya Oleh Pihak Ketiga Dalam Bentuk Izin Pemakaian Tanah (Perspektif Hukum Pertanahan)

atas tanah lainnya sebagaimana diatur dalam UUPA. Berdasarkan pengertian Izin Pemakaian Tanah ini menunjukkan bahwa Izin Pemakaian Tanah diberikan oleh Walikotamadya Kepala Daerah atau pejabat yang ditunjuk yaitu Kepala Dinas Pengelolaan Bangunan dan Tanah, Maksud diterbitkan Izin Pemakaian Tanah adalah untuk memakai tanah, dan Hak yang diberikan kepada pemegang Izin Pemakaian Tanah adalah bukan Hak Pakai atau hak-hak atas tanah lainnya sebagaimana diatur dalam UUPA. Hak yang diperoleh pemegang Izin Pemakaian Tanah bukan Hak Milik, Hak Guna Bangunan, atau Hak Pakai, melainkan memakai yang bukan hak atas tanah.

Berdasarkan ketentuan Pasal 1 huruf e Peraturan Daerah Kotamadya Daerah Tingkat II Surabaya No. 1 Tahun 1997 juncto Pasal 1 huruf f Keputusan Walikotamadya Kepala Daerah Tingkat II Surabaya No. 1 Tahun 1998, tanah yang diterbitkan Izin Pemakaian Tanah adalah tanah milik dan atau dikuasai/dikelola oleh Pemerintah Kotamadya Daerah Tingkat II Surabaya milik menunjukkan bahwa status tanahnya adalah Hak Milik. Pemerintah Kota Surabaya bukan subjek Hak Milik, melainkan subjek Hak Pakai dan Hak Pengelolaan. Kata dikuasai (garis bawah penulis) disini mengandung pengertian bahwa status tanahnya adalah Hak Pakai. Kata dikelola (garis bawah penulis) disini mengandung pengertian bahwa status tanahnya adalah Hak Pengelolaan.

Dalam Surat Izin Pemakaian Tanah Kota Surabaya pada halaman terakhir angka 6 dinyatakan bahwa: "Untuk mengagunkan bangunan sendiri di atas tanah sewa milik Pemerintah Kota Surabaya terlebih dahulu harus mendapat izin tertulis dari Walikota atau pejabat yang ditunjuk". Berdasarkan ketentuan ini menunjukkan bahwa Pemerintah Kota Surabaya menyewakan tanah miliknya kepada pihak lain. Pemerintah Kota Surabaya tidak mempunyai kewenangan untuk menyewakan tanah yang dikuasainya berupa Hak Pakai dan Hak Pengelolaan kepada pihak ketiga. Tanah yang dapat disewakan hanya tanah yang berstatus Hak Milik sebagaimana ditetapkan dalam Pasal 44 UUPA. Pemerintah Kota Surabaya bukan subjek Hak Milik, melainkan subjek Hak Pakai dan Hak Pengelolaan.

Kalau Pemerintah Kota Surabaya mempunyai tanah aset berupa Hak Pakai, maka kewenangannya adalah mempergunakan tanah Hak Pakai untuk pelaksanaan tugasnya. Kalau Pemerintah Kota
Surabaya mempunyai tanah aset berupa Hak Pengelolaan, maka kewenangannya adalah merencanakan peruntukan dan penggunaan tanah, mempergunakan tanah untuk keperluan pelaksanaan tugasnya, dan menyerahkan bagian-bagian tanah Hak Pengelolaan kepada pihak ketiga dan atau bekerja sama dengan pihak ketiga.

Penggunaan tanah Hak Pakai dan Hak Pengelolaan aset Pemerintah Kota Surabaya oleh pihak ketiga dalam bentuk Izin Pemakaian Tanah merupakan penyimpangan kewenangan oleh Pemerintah Kota Surabaya terhadap tanah Hak Pakai dan Hak Pengelolaannya. Pemerintah Kota Surabaya tidak mempunyai kewenangan menerbitkan Izin Pemakaian Tanah di atas tanah Hak Pakai dan Hak Pengelolaannya.

Pihak ketiga yang ingin mempergunakan tanah Hak Pakai aset Pemerintah Kota Surabaya ditempuh melalui pelepasan tanah Hak Pakai oleh Walikota Surabaya setelah mendapatkan persetujuan dari Dewan Perwakilan Rakyat Daerah Kota Surabaya. Dengan pelepasan tanah Hak Pakai tersebut, maka tanah Hak Pakai menjadi hapus dan kembali menjadi tanah Negara atau tanah yang dikuasai langsung oleh Negara. Selanjutnya dimohonkan hak atas tanah baru oleh pihak yang membutuhkan tanah Hak Pakai kepada Menteri Agraria dan Tata Ruang/Kepala Badan Pertanahan Nasional Republik Indonesia melalui Kepala Kantor Pertanahan Kota Surabaya. Pihak ketiga yang ingin mempergunakan tanah Hak Pakai aset Pemerintah Kota Surabaya juga dapat ditempuh melalui pelepasan tanah Hak Pakai oleh Walikota Surabaya setelah mendapatkan persetujuan dari Dewan Perwakilan Rakyat Daerah Kota Surabaya. Pelepasan tanah Hak Pakai tersebut untuk diubah menjadi Hak Pengelolaan, yaitu Walikota Surabaya mengajukan permohonan Hak Pengelolaan kepada Menteri Agraria dan Tata Ruang/Kepala Badan Pertanahan Nasional Republik Indonesia melalui Kepala Kantor Pertanahan Kota Surabaya. Dengan perubahan Hak Pakai menjadi Hak Pengelolaan, maka selanjutnya Pemerintah Kota Surabaya memberikan bagian tanah Hak Pengelolaannya kepada pihak ketiga dalam bentuk Penyerahan Penggunaan Tanah, atau Perjanjian Bangun Guna Serah.

Pihak ketiga yang ingin mempergunakan tanah Hak Pengelolaan aset Pemerintah Kota Surabaya 
ditempuh melalui Perjanjian Penyerahan Penggunaan Tanah, atau Perjanjian Bangun Guna Serah antara Pemerintah Kota Surabaya dan pihak ketiga. Perjanjian Penyerahan Penggunaan Tanah, atau Perjanjian Bangun Guna Serah dapat dibuat dengan akta di bawah tangan atau akta notaris.

Izin Pemakaian Tanah bila dikaji dari Peraturan Pemerintah No. 6 Tahun 2006 tentang Pengelolaan Barang Milik Negara/Daerah. Peraturan Pemerintah No. 6 Tahun 2006 diubah oleh Peraturan Pemerintah No. 38 Tahun 2008 tentang Pengelolaan Barang Milik Negara/Daerah. Peraturan Pemerintah No. 38 Tahun 2008 tentang Pengelolaan Barang Milik Negara/ Daerah dinyatakan tidak berlaku oleh Peraturan Pemerintah No. 27 Tahun 2014 tentang Pengelolaan Barang Milik Negara/Daerah. Dalam Pasal 27 Peraturan Pemerintah No. 27 Tahun 2014 dinyatakan bahwa bentuk-bentuk pemanfaatan barang milik negara/daerah, adalah: a. Sewa, b. Pinjam pakai, c. Kerjasama pemanfaatan, d. Bangun guna serah dan bangun serah guna, e. Kerjasama penyediaan infrastruktur. Berdasarkan ketentuan ini, pemakaian tanah Hak Pakai dan Hak Pengelolaan yang dikuasai oleh Pemerintah Kota Surabaya oleh pihak ketiga dalam bentuk Izin Pemakaian Tanah tidak termasuk bentuk pemanfaatan barang milik negara/daerah berupa tanah oleh pihak ketiga.

Pasal 27 Peraturan Pemerintah No. 27 Tahun 2014 dinyatakan bahwa salah satu pemanfaatan barang milik negara/daerah adalah sewa. Berdasarkan ketentuan ini, barang milik daerah berupa tanah dapat disewakan oleh Pemerintah Daerah kepada pihak ketiga. Status tanah yang dikuasai oleh Pemerintah Daerah adalah Hak Pakai dan Hak Pengelolaan. Pemerintah Daerah yang menguasai tanah Hak Pakai dan Hak Pengelolaan tidak mempunyai kewenangan untuk menyewakan tanah Hak Pakai dan Hak Pengelolaannya kepada pihak ketiga disebabkan status tanah yang dapat disewakan oleh pemegangnya adalah hanya tanah Hak Milik sebagaimana ditetapkan dalam Pasal 44 UUPA. Pasal 27 Peraturan Pemerintah No. 27 Tahun 2014 bertentangan dengan Pasal 44 UUPA.

Pemerintah Kota Surabaya melalui Dinas Pengelolaan Bangunan dan Tanah menetapkan kewajiban membayar retribusi bagi pemegang Izin Pemakaian Tanah. Retribusi atas Izin Pemakaian Tanah bila dikaji dari Undang-Undang No. 28 Tahun
2009 tentang Pajak Daerah dan Retribusi Daerah kurang tepat. Menurut Pasal 1 angka 64 UndangUndang No. 28 Tahun 2009, yang dimaksud retribusi daerah, atau selanjutnya retribusi dan pungutan daerah sebagai pembayaran atas jasa atau pemberian izin tertentu yang khusus disediakan dan/atau diberikan oleh Pemerintah Daerah untuk kepentingan orang pribadi atau badan. Berdasarkan ketentuan Pasal 1 angka (64) Undang-Undang No. 28 Tahun 2009 , orang atau badan hukum yang memiliki izin yang diterbitkan oleh Pemerintah Daerah dikenakan retribusi.

Pasal 108 ayat (1) Undang-Undang No. 28 Tahun 2009 menetapkan objek retribusi daerah adalah: Jasa umum; Jasa usaha; dan Perizinan tertentu. Pasal 141 Undang-Undang No. 28 Tahun 2009 menetapkan jenis retribusi perizinan tertentu, yaitu: Retribusi Izin Mendirikan Bangunan; Retribusi Izin Tempat Penjualan Minuman Beralkohol; Retribusi Izin Gangguan; Retribusi Izin Trayek; dan Retribusi Izin Usaha Perikanan. Berdasarkan ketentuan Pasal 141 Undang-Undang No. 28 Tahun 2009, Izin Pemakaian Tanah tidak termasuk izin yang dikenakan retribusi. Pasal 127 huruf a Undang-Undang No. 28 Tahun 2009 menetapkan bahwa pemakaian kekayaan daerah termasuk jenis jasa usaha yang dikenakan retribusi. Berdasarkan Pasal 127 huruf a UndangUndang No. 28 Tahun 2009, kalau Izin Pemakaian Tanah dimasukkan ke dalam pemakaian kekayaan daerah yang dikenakan retribusi, maka hal ini dapat dibenarkan sepanjang dapat dibuktikan bahwa tanah yang diterbitkan Izin Pemakaian Tanah adalah tanah Hak Pakai atau Hak Pengelolaan yang dikuasai oleh Pemerintah Kota Surabaya. Sebaliknya, apabila tidak dapat dibuktikan bahwa tanah yang diterbitkan Izin Pemakaian Tanah adalah tanah Hak Pakai atau Hak Pengelolaan yang dikuasai oleh Pemerintah Kota Surabaya, maka pengenaan retribusi atas Izin Pemakaian Tanah tidak dapat dibenarkan.

\section{PENUTUP \\ Kesimpulan}

Tanah aset yang dikuasai oleh Pemerintah Kota Surabaya berstatus Hak Pakai dan Hak Pengelolaan. Hak Pakai dan Hak Pengelolaan bersifat right to use tidak bersifat right of dispossal, yaitu hanya berhak mempergunakan tanah selama tanahnya dipergunakan untuk keperluan pelaksanaan tugasnya, 
Urip Santoso,

Penggunaan Tanah Aset Pemerintah Kota Surabaya Oleh Pihak Ketiga Dalam Bentuk Izin Pemakaian Tanah (Perspektif Hukum Pertanahan)

tidak ada kewenangan untuk memindahkan hak atau menjadikan haknya sebagai jaminan utang dengan dibebani Hak Tanggungan. Izin Pemakaian Tanah adalah izin yang diterbitkan oleh Walikota Surabaya atau pejabat yang ditunjuk yaitu Kepala Dinas Pengelolaan Bangunan dan Tanah kepada perseorangan atau badan hukum Indonesia untuk memakai tanah aset Pemerintah Kota Surabaya dalam jangka waktu tertentu dengan membayar retribusi bagi pemegang Izin Pemakaian Tanah. Izin Pemakaian Tanah merupakan bentuk penggunaan tanah aset Pemerintah Kota Surabaya oleh pihak ketiga. Dari kajian Hukum Pertanahan Nasional, Izin Pemakaian Tanah merupakan penyimpangan kewenangan oleh Pemerintah Kota Surabaya terhadap tanah Hak Pakai dan Hak Pengelolaannya.

\section{Rekomendasi}

Izin Pemakaian Tanah yang diatur dalam Peraturan Daerah Kotamadya Daerah Tingkat II Surabaya No. 1 Tahun 1997 dan Keputusan Walikotamadya Kdepala Daerah Tingkat II Surabaya No. 1 Tahun 1998 perlu ditinjau kembali disebabkan bertentangan dengan Hukum Pertanahan Nasional yang diatur dalam UUPA.

Izin Pemakaian Tanah sebagai bentuk penggunaan tanah Hak Pakai dan Hak Pengelolaan yang dikuasai oleh Pemerintah Kota Surabaya oleh pihak ketiga perlu ditinjau kembali disebabkan Pemerintah Kota Surabaya tidak punyai kewenangan untuk memperkenankan tanah Hak Pakai dan Hak Pengelolaannya dipergunakan oleh dalam bentuk Izin Pemakaian Tanah.

Hanya tanah yang berstatus Hak Pengelolaan Pemerintah Kota Surabaya yang dapat dipergunakan oleh pihak ketiga adalah dalam bentuk perjanjian penyerahan penggunaan tanah atau Perjanjian Bangun Guna Serah antara Pemerintah Kota Surabaya dan pihak ketiga.

\section{DAFTAR PUSTAKA}

\section{Peraturan Perundang-undangan:}

Undang-Undang Nomor 5 Tahun 1960 tentang Peraturan Dasar Pokok-Pokok Agraria.

Undang-Undang Nomor 20 Tahun 2000 tentang Perubahan Atas Undang-Undang Nomor 21 Tahun 1997 tentang Bea Perolehan Hak Atas Tanah dan Bangunan.
Undang-Undang Nomor 28 Tahun 2009 tentang Pajak Daerah dan Retribusi Daerah.

Peraturan Pemerintah Nomor 40 Tahun 1996 tentang Hak Guna Usaha, Hak Guna Bangunan, dan Hak Pakai Atas Tanah.

Peraturan Pemerintah Nomor 40 Tahun 1996 tentang Pendaftaran Tanah.

Peraturan Pemerintah Nomor 112 Tahun 2000 tentang Pengenaan Bea Perolehan Hak Atas Tanah dan Bangunan Karena Pemberian Hak Pengelolaan. Peraturan Pemerintah Nomor 27 Tahun 2014 tentang Pengelolaan Barang Milik Negara/Daerah.

Peraturan Menteri Agraria Nomor 9 Tahun 1965 tentang Pelaksanaan Konversi Hak Penguasaan Atas Tanah Negara dan Kebijaksanaan Selanjutnya.

Peraturan Menteri Agraria Nomor 1 Tahun 1966 tentang Pendaftaran Hak Pakai dan Hak Pengelolaan

Peraturan Menteri Negara Agraria/Kepala Badan Pertanahan Nasional Nomor 9 Tahun 1999 tentang Tata Cara Pemberian dan Pembatalan Pemberian Hak Atas Tanah Negara dan Hak Pengelolaan.

Peraturan Daerah Kotamadya Daerah Tingkat II Surabaya Nomor 1 Tahun 1997 tentang Izin Pemakaian Tanah.

Keputusan Walikotamadya Kepala Daerah Tingkat II Surabaya Nomor 1 Tahun 1998 tentang Tata Cara Penyelesaian Izin Pemakaian Tanah.

\section{Buku:}

Arief Shidarta. (1996). Refleksi Tentang Hukum Pengertian-Pengertian Dasar Dalam Teori Hukum. Bandung: Citra Aditya Bakti.

Boedi Harsono. (2003). Hukum Agraria Indonesia Sejarah Pembentukan Undang-Undang Pokok Agraria Isi dan Pelaksanaannya. Jakarta: Djambatan.

\section{Jurnal:}

A.P. Parlindungan. (Maret-April 1991). "Beberapa Konsep tentang Hak-Hak Atas Tanah". Majalah CSIS. Jakarta. Tahun XX No. 2, h. 135.

Lilik Pudjiastuti. "Kewenangan Pelayanan Perizinan di Pemerintah Kota Surabaya dengan Diberlakukannya Undang-Undang No. 22 Tahun 1999”. Majalah YURIDIKA. Vol. XVII No. 6 
November-Desember 2003. Surabaya: Fakultas Hukum Universitas Airlangga, h. 556.

Philipus M. Hadjon. (1993). "Pengantar Hukum Perizinan". YURIDIKA. Surabaya: Fakultas Hukum Universitas Airlangga, h. 2.

Tatiek Sri Djatmiati. "Kerjasama Antar Daerah Dalam Bidang Perizinan". Majalah YURIDIKA. Vol. XX No. 4 Juli-Agustus 2005. Surabaya: Fakultas Hukum Universitas Airlangga, h. 258. Fani Martiawan Kumara Putra. (2013). "Tanggung Gugat Debitur Terhadap Hilangnya Hak Atas
Tanah Dalam Obyek Jaminan Hak Tanggungan”. Yuridika. Fakultas Hukum Universitas Airlangga Surabaya. Volume 28 Nomor 2 Edisi Mei, h. 102115.

Fani Martiawan Kumara Putra. (2015). "Pembatalan Sertifikat Hak Atas Tanah Karena Cacat Administratif Serta Implikasinya Apabila Hak Atas Tanah Sedang Dijaminkan”. Perspektif. Fakultas Hukum Universitas Wijaya Kusuma Surabaya. Volume 20 No. 2 Edisi Mei, h. 101117. 